\title{
23. A kivételes állapot alkotmányos és törvényi szintû́ szabályozása Svédországban
}

\author{
UNGVÁRI ÁLMOS
}

\section{A különleges jogrend alkotmányos és törvényi szintű szabályozása}

Svédország alkotmánya ${ }^{1}$ - amelynek fejlődése európai és skandináv vonatkozásban is különleges - formáját tekintve közbülső helyet foglal el az írott, kontinentális (chartális) és az íratlan (történeti) angol alkotmány között. ${ }^{2} \mathrm{Az}$ ugyanis nem egy egységes dokumentum, hanem négy úgynevezett alaptörvény (grundlagar), a kormányzatról szóló törvény, ${ }^{3}$ a trónöröklés rendjét rögzítő öröklési törvény, ${ }^{4}$ a sajtó szabadságának garanciái mellett a közérdekű dokumentumok nyilvánosságát is szabályozó sajtószabadságról szóló törvény, ${ }^{5}$

I A svéd alkotmányos rendszer legfontosabb törvényeinek angol nyelvü, rövid magyarázattal ellátott gyüjtését lásd: Isberg, 2016.

2 Kiss, 1991, 168. o.

3 Regeringsformen-Kungörelse (1974:152) om beslutad ny regeringsform (a továbbiakban: Kormányzati tv.).

4 Successionsordning (1810:0926).

5 Tryckfrihetsförordning (1949:105) (a továbbiakban: Sajtószab.tv.).

Dr. Ungvári Álmos

almos.ungvari@mfi.gov.hu

kutató (Mádl Ferenc Összehasonlító Jogi Intézet)

PhD-hallgató (Pázmány Péter Katolikus Egyetem, Jog- és Államtudományi Doktori Iskola)

Ungvári, Á. (2021) 'A kivételes állapot alkotmányos és törvényi szintû szabályozása Svédországban' in Nagy, Z., Horváth, A. (szerk.) A különleges jogrend és nemzeti szabályozási modelljei, 504-529. o. Budapest: Mádl Ferenc Összehasonlító Jogi Intézet.

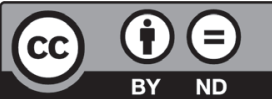


illetve a véleménynyilvánítás szabadságáról szóló törvény ${ }^{6}$ együttesen alkotja. ${ }^{7}$ Ugyan nem sorolják az alaptörvények közé, azonban a svéd alkotmányos rendszer fontos pillére a törvényhozás szervezetének és múködésének szabályait rögzítő, a parlamentről (Riksdag) szóló törvény ${ }^{8}$ is. Központi alaptörvényként a leginkább alkotmány jellegú, a hatalomgyakorlás alapjait, az alapvető jogokat, illetve az államszervezet felépítését és múködését rögzítő Kormányzati tv.-re szoktak hivatkozni. A különleges jogrend tárgyköre kapcsán is ez a jogszabály bír relevanciával.

A svéd jogi doktrína a kivételes állapotok három fajtáját különbözteti meg: a háborút (az állam elleni külső támadást), a rendkívüli körülményeket, valamint a (belső) szükségállapotot. ${ }^{9}$ Azonban különleges jogrendi helyzetként egyedül az elsőt rögzítették alkotmányos szinten, ugyanis a Kormányzati tv. önálló fejezetben rendelkezik a háború és háborús veszély kategóriáiról. Ugyanakkor - hasonlóan egyébként a norvég és a dán alkotmányhoz hallgat a békeidejú kivételes szituációkról, azok vonatkozásában nem tartalmaz különleges szabályokat. ${ }^{10} \mathrm{~A}$ svéd megközelítés szerint a háborúnak nem minősülő válsághelyzetek kezelése a rendes jogrend szerint - a jogállamiság alapelveinek megtartásával - történik, azaz a rendes jogrendi jogszabályok keretében kell biztosítani a kivételes állapotra való hatékony reakciót. ${ }^{11}$ Ezt az alkotmányos készültség (Författningsberedskap) kifejezéssel írják le, ${ }^{12}$ amelynek keretében számos törvényt és rendeletet alkottak a háborús helyzetre, a rendkívüli eseményekre való felkészülés, valamint azok kezelése érdekében. A kivételes állapoti kategóriák fenti hármasából tehát az első kettő törvényileg meghatározott, ám a - többek között - terrorcselekmény, szervezett bủnözés, komolyabb baleset, természeti katasztrófa, járvány vagy a kritikus infrastruktúra múködésének zavara következményeként jelentkező szükségállapoti helyzet sem alkotmányos, sem alacsonyabb jogszabályi szinten nincs rögzítve. És bár föszabály szerint ilyen és ehhez hasonló esetekben is a rendes jogi normák irányadók, hiszen nem minősülnek alkotmányos értelemben vett háborús szituációnak, mégis kialakult egyfajta - az alkotmányos elv szintjét még talán el nem érő - különleges jogrendi gyakorlat. Tekintettel arra, hogy ez a gyakorlat néhány, az 1970-es években bekövetkezett esemény hatására alakult ki, a békeidejủ szükségállapot alkotmányos szinten való rögzítése már a Kormányzati tv. elôkészítése során is vitát generált, és bár annak elfogadásával a különleges jogrendi hatalomgyakorlás egyedül háború idején vált legitimálhatóvá, a kérdés újra és újra felmerül. ${ }^{13}$ Ezt a problémát járta körül a válságra való felkészülésről szóló

6 Yttrandefrihetsgrundlag (1991:1469) (a továbbikban: Vélemény tv.).

7 Nergelius, 2019, 316. o.

8 Riksdagsordning (2014:801) (a továbbiakban: Parlamenti tv.).

9 Hirschfeldt, 2017, 194. o.

10 Cameron-Jonsson Cornell, 2020, 1175. o.; Dibb, 2020, 535. o.; Hirschfeldt, 2020, 1148. o.

11 Jonsson Cornell, 2020, 377. o.

12 Cameron-Jonsson Cornell, 2020, 1177. o.

13 Jonsson Cornell-Salminen, 2018, 227-228. o. 
alkotmányos szabályokat áttekintő 2008 -as állami jelentés, ${ }^{14}$ amelynek nyomán javaslat ${ }^{15} \mathrm{ké}^{-}$ szült a Kormányzati tv. háborús rendelkezéseinek kibővitésére, ám a 2011. január 1-jén hatályba lépő - a központi alaptörvény jelentős reformját hozó - módosítások ${ }^{16}$ érdemben nem változtatták meg a különleges jogrendi fejezetet.

\subsection{Háború és háborús veszély}

A Kormányzati tv. 15., Háború és háborús veszély ${ }^{17}$ címú fejezete döntően hatásköri szabályokat tartalmaz,18 ellenben a különleges jogrendi helyzeteket nem definiálja. Konszenzus alakult ki annak kapcsán, hogy a háború fogalmát nem lehet jogszabályban meghatározni, a különleges jogrend elrendeléséről a kormány dönt, egyedül az állam részben vagy egészben történő megszállása esetén érvényesülnek automatikusan a háborús szabályok. ${ }^{19}$ A Kormányzati tv. értelmében azonban a kormány csak parlamenti felhatalmazás alapján hirdetheti ki a hadiállapotot, ezalól kizárólag az államot érő fegyveres támadás képez kivételt. ${ }^{20}$

Ha a Svéd Királyság háborúba kerül vagy háborús veszélynek van kitéve, a kormány vagy a házelnök - akár Stockholmon kívül eső helyre - összehívja a parlamentet. Abban az esetben viszont, ha a körülmények azt indokolják, a parlament a házelnökből és ötven másik, a parlament által választott tagból állón ${ }^{21}$ Haditanácsnak (Krigsdelegationen) adja át a helyét. Az erről szóló rendelkezés a miniszterelnök és a Külügyi Tanácsadó Testület (Utrikesnämndens) együttmúködését igényli. Amennyiben ugyanis a királyság háborúban áll, a miniszterelnökkel való egyeztetést követően a Külügyi Tanácsadó Testület tagjai, ha pedig az állam háború közvetlen veszélyének van kitéve, a Külügyi Tanácsadó Testület tagjai és a miniszterelnök közösen döntenek a hatáskör-átruházásról. Utóbbi esetben a rendelkezés érvényességéhez a miniszterelnök és a Külügyi Tanácsadó Testület hat tagjának egyetértése szükséges. Kivételesen pedig - ha a háborús körülmények megakadályozzák a Külügyi Tanácsadó Testület összeülését - a kormány is határozhat erről. ${ }^{22}$ Amíg helyettesíti - az alaptörvény nem határoz meg határidőt az illetékességére vonatkozóan -, a Haditanács a parlament valamennyi

14 Krisberedskapen i grundlagen - Översyn och internationell utblick. Expertgruppsrapport, Grundlagsutredningens rapport XIII Stockholm, 2008 (a továbbiakban: SOU 2008:61.). Elérhetô: www.regeringen.se/49bb8d/ contentassets/od28bo2e5ee046a8b4549ac4eb9874af/krisberedskapen-i-grundlagen-sou-200861 (Letöltve: 2020. november 30.).

15 En reformerad grundlag. Betänkande av Grundlagsutredningen. Stockholm, 2008 (a továbbiakban: SOU 2008:125.). Elérhető: www.regeringen.se/rattsliga-dokument/statens-offentliga-utredningar/2008/12/sou2008125/ (Letöltve: 2020. november 30.).

16 A Kormányzati tv. reformjáról bővebben lásd: Nergelius, 2013, 372-379. o.

17 Krig och krigsfara.

18 Csink, 2017, 12. o.

19 SOU 2008:61. 28., 47-48. o.

20 Kormányzati tv. 15. fejezet 14. cikk.

21 Parlamenti tv. 13. fejezet 11. \$.

22 Kormányzati tv. 15. fejezet 1-2. cikk. 
hatáskörét gyakorolhatja, így törvényeket, sőt akár alaptörvényt is alkothat és módosíthat. Egyedül a parlamenti választásokkal kapcsolatos szabályok képeznek kivételt. Arról, hogy a parlament ismételten betöltheti-e hatáskörét - közös tárgyalás útján vagy külön-külön -, a Haditanács és a kormány jogosult dönteni. ${ }^{23} \mathrm{~A}$ Kormányzati tv. tehát megerősíti a törvényhozó hatalom pozícióját háború idején, a parlament kompetenciáinak a Haditanácsra való átruházásával pedig biztosítja, hogy minden körülmények között legyen egy olyan, az arányosság elvét tiszteletben tartó törvényhozó testület, amely méretéből adódóan a háborús szituáció során is megfelelően tud múködni, ugyanakkor biztosítja a kellô mértékú reprezentativitást is. ${ }^{24}$ Szintén a parlament jogkörét erősíti, hogy ha a háború vagy háborús veszély következtében a kormány nem képes ellátni feladatait, dönthet annak felállításáról, és meghatározhatja ügyrendjét. ${ }^{25} \mathrm{~A}$ parlament múködésének biztosítására szolgáló fontos garanciális szabály az is, hogy parlamenti választást háború idején kizárólag a parlament döntése alapján lehet tartani, ha pedig a Svéd Királyság háborús veszélynek van kitéve az általános választások tervezett idejében, azt elhalaszthatja, ám ehhez mindkét esetben a képviselők háromnegyedes többsége szükséges. A parlamenti választásról szóló döntést legalább évente felül kell vizsgálni, és azok megtartására a különleges jogrendi helyzet elmúltával a lehetố leghamarabb sort kell keríteni. ${ }^{26}$

A Kormányzati tv. arra az esetre is tartalmaz rendelkezéseket, amikor sem a parlament, sem pedig a Haditanács nem képes feladatait ellátni. Ilyenkor a királyság védelme és a háború befejezése érdekében - a szükséges mértékben - a kormány gyakorolja a törvényhozói hatáskört. Ez alapján a kormány rendeletével szabályozhat törvényi útra tartozó területeket. Emellett - az olyan felhatalmazási törvényeket megalapozandó, ${ }^{27}$ mint a kisajátítást és kártalanítást szabályozó ${ }^{28}$ vagy a meghatározott áruk háború idején való forgalmazásának korlátozásáról ${ }^{29}$ szóló törvény - azt is rögzíti, hogy a védelmi készültség szempontjából szükséges bármely más esetben törvény felhatalmazása alapján a kormány rendeleti úton dönthet valamely törvényi szintú, igénybevétellel kapcsolatos vagy más hasonló rendelkezés hatálybalépéséről vagy alkalmazásának megszüntetéséről. Ez utóbbi esetben a törvény körül kell hogy határolja a felhatalmazás alkalmazásának feltételeit. Fontos azonban, hogy a rendeleti kormányzás keretében a kormány nem hozhat, nem módosíthat és nem helyezhet hatályon kívül alaptörvényt, illetve a parlamentről és a parlamenti választásokról szóló törvényt. Érdemes kiemelni, hogy a kormány kivételes rendeletalkotási jogkörének alapjaként nemcsak a háborút és a háborús veszélyt nevesíti a Kormányzati tv., hanem az azok követ-

23 Kormányzati tv. 15. fejezet 3. cikk.

24 SOU 2008:61. 29. 0.

25 Kormányzati tv. 15. fejezet 4. cikk.

26 Kormányzati tv. 15. fejezet 11. cikk.

27 SOU 2008:61. 33. 0.

28 Förfogandelag (1978:262).

29 Ransoneringslag (1978:268). 
keztében elóállt rendkívüli körülményeket is. ${ }^{30} \mathrm{~A}$ rendkívüli jogalkotási felhatalmazáson túl a kormány - a parlament döntése nyomán - más hatóság hatáskörébe utalhatja a központi alaptörvény szerint egyébként rá tartozó feladatokat. ${ }^{31}$

Külön rendelkezéseket találhatunk a Svéd Királyság megszállása vonatkozásában. Az elfoglalt területekkel kapcsolatban sem a parlament, sem a kormány nem hozhat döntést, ott egyik szerv tagja sem gyakorolhat hatáskörébe és felelőssége alá tartozó feladatokat. Ezeken a területeken minden közhatalmi szerv köteles megtenni mindazt, ami a legjobban szolgálja a védelmet, az ellenállási mozgalmat, a polgári lakosság védelmét, illetve Svédország külpolitikai érdekeit. Azonban semmilyen körülmények között nem folytathat közhatalmi szerv olyan tevékenységet, amely ellentétes a nemzetközi joggal, vagy amely a megszálló erőket szolgálja. ${ }^{32}$

A Kormányzati tv. mellett több más jogszabály is rendelkezik a hadiállapot kezelésének kérdéséről. ${ }^{33}$ Ezek közül kiemelendő az ország háborúra való felkészülését szabályozó, a teljes védelemről és készültségről szóló törvény, ${ }^{34}$ amelynek értelmében a polgári és katonai dimenzióval egyaránt rendelkező védelmi tevékenység megerősitése érdekében a kormány dönthet a többfokozatú készültség indokolt szintjének bevezetéséről. Ez háború idején automatikusan a legmagasabb készültséget jelenti, míg háborús veszély esetén a kormány dönthet annak fokozatáról. A készültségről szóló határozat hatálya kiterjedhet kizárólag egyes országrészekre vagy tevékenységekre is..$^{35} \mathrm{~A}$ társadalom rendes múködésének biztosítása, sebezhetőségének csökkentése érdekében a felelős hatóságok teljes védelem megtervezésére ${ }^{36}$ és készültségi intézkedésekre ${ }^{37}$ vonatkozó kötelezettségét rendeletek rögzítik. Ezek értelmében a készültség esetén a szükséges előkészületi tevékenységek elvégzéséért felelős hatóságok - amelyek köre a rendelet mellékletében rögzítésre került - készenléti tervvel kell hogy rendelkezzenek, személyzetüket kötelesek felkészíteni, illetve a készültség során tevékenységüket elsősorban a teljes védelem szempontjából fontos feladatokra kell korlátozniuk..$^{38}$ Emellett az események alakulásáról, a tervezett és megvalósított intézkedésekről folyamatosan tájékoztatniuk kell a kormányt, a fegyveres erők vonatkozásában pedig dokumentációszolgáltatási kötelezettségük van. ${ }^{39}$ Ezenfelül rendeletben rögzítik a hatóságok

30 Kormányzati tv. 15. fejezet 5-6. cikk.

31 Kormányzati tv. 15. fejezet 8 . cikk.

32 Kormányzati tv. 15. fejezet 9. cikk.

33 Említésre érdemes: az óvóhelyekről szóló törvény [Lag (2006:545) om skyddsrum], valamint a katonai mozgósításról szóló törvény [Lag (1994:1809) om totalförsvarsplikt] is.

34 Lag (1992:1403) om totalförsvar och höjd beredskap (a továbbiakban: Védelmi tv.).

35 Védelmi tv. 1-4. \$.

36 Förordning (2015:1053) om totalförsvar och höjd beredskap (a továbbiakban:Védelmi r.).

37 Förordning (2015:1052) om krisberedskap och bevakningsansvariga myndigheters åtgärder vid höjd beredskap (a továbbiakban: Válság r.).

38 Válság r. 15-17. \$; Védelmi r. 4-6.\$.

39 Válság r. 18. \$; Védelmi r. 7-8. \$. 
kötelező együttmúködési területeit, ${ }^{40}$ a készültségrôl szóló döntések kihirdetésének, ${ }^{41}$ valamint a fegyveres erők hadra hívásának szabályait ${ }^{42}$ is. A készültség során az önkormányzatok és régiók is kötelesek a mûvveletek összehangolására és a rendelkezésre álló erőforrások felhasználásának biztosítására szolgáló rendkívüli intézkedéseket hozni, ${ }^{43}$ ezzel kapcsolatos feladataikat az önkormányzatok és régiók békeidőben bekövetkező rendkívüli eseményekkel kapcsolatos intézkedéseirôl szóló törvényben ${ }^{44}$ és annak rendeletében ${ }^{45}$ találjuk meg. A települések és régiók kötelesek megtenni a készültségi tevékenységekhez szükséges előkészítő intézkedéseket. Erről és a rendkívüli események alakulásáról folyamatosan tájékoztatniuk kell a megyei igazgatóságot és a hatáskörrel rendelkező kormányzati szervet. ${ }^{46} \mathrm{~A}$ készültség során a regionális igazgatóság felel a polgári védelem és az egészségügyi ellátás irányításáért, az olyan helyi szintû válságkezelési tevékenységek, mint például a szükséges áruk biztosítására irányuló intézkedések, illetve az árszabályozás az önkormányzat hatáskörébe tartoznak. ${ }^{47} \mathrm{~A}$ készültség megszüntetéséről - amennyiben az elrendelésére okot adó körülmények már nem állnak fenn - a kormány dönthet. ${ }^{48}$

Rendelet rögzíti azon törvények körét is, amelyek a készültség keretében háborús helyzetben automatikusan hatályba lépnek. ${ }^{49}$ Így háború vagy háborús veszély során - a fentiekben említett két felhatalmazási törvény mellett - alkalmazandóvá válik többek között a háborús körülmények közötti fizetési rendszerről, ${ }^{50}$ a hajók átruházásának tilalmáról,,$^{51}$ a vízenergia háborúban történő felhasználásáról,,$^{52}$ a háborús határơrizetről,,$^{53}$ a háborús kereskedelemről, ${ }^{54}$ a rendkívüli munkajogi szabályokról, ${ }^{55}$ a kötelező foglalkoztatásról, ${ }^{56} \mathrm{va}-$ lamint az árszabályozásról ${ }^{57}$ szóló törvény is. Megállapítható ez alapján, hogy a svéd jogrend az alkotmányos felkészültség elvének megfelelően - számos jogszabályt tartalmaz a háború és a háborús veszély kezelésére, azonban a Kormányzati tv. lehetőséget biztosít az ezektől

40 Válság r. 7. \$.

41 Védelmi r. 9-10. \$.

42 Védelmi r. 11. \$.

43 Védelmi tv. 7. \$.

44 Lag (2006:544) om kommuners och regioners åtgärder inför och vid extraordinära händelser i fredstid och höjd beredskap (a továbbiakban: Rendkívüli események tv.).

45 Förordning (2006:637) om kommuners och regioners åtgärder inför och vid extraordinära händelser i fredstid och höjd beredskap (a továbbiakban: Rendkívüli események r.).

46 Rendkívüli események tv. 3. fejezet 1. és 5. \$; Rendkívüli események r. 4. és 6-7. \$.

47 Rendkívüli események tv. 3. fejezet 3. \$.

48 Védelmi tv. 5. $\$$.

49 Védelmi r. 13. \$.

50 Lag (1957:684) om betalningsväsendet under krigsförhållanden.

51 Lag (1939:299) om förbud i vissa fall mot överlåtelse eller upplåtelse av fartyg m.m.

52 Lag (1962:627) om utnyttjande av vattenkraft vid krig.

53 Lag (1979:1088) om gränsövervakningen i krig m.m.

54 Krigshandelslag (1964:19).

55 Arbetsrättslig beredskapslag (1987:1262).

56 Lag (1994:2077) om arbetsförmedlingstvång.

57 Prisregleringslag (1989:978). 
való eltérésre. Ugyanakkor az alkotmányos szabályozás különleges jogrend idején is törekszik arra, hogy a kormány által gyakorolható rendeleti kormányzásra csak végső esetben kerüljön sor. Említésre érdemes, hogy míg a háborús helyzet kihirdetése és kezelése során a parlament és a kormány egyaránt fontos szerepet játszik, az államfő - szemben több más európai állam, így például Magyarország szabályozásával - nem rendelkezik különleges jogrendi hatáskörökkel. Igaz, a svéd király hatásköre rendes körülmények között is leginkább reprezentatív funkciókra korlátozódik. ${ }^{58}$

\subsection{Békeidejü kivételes szituációk}

Ismételten érdemes megjegyezni, hogy alkotmányos szinten egyedül a háború vonatkozásában beszélhetünk különleges jogrendi rendelkezésekről, a más típusú, békeidőben jelentkező válságokkal szemben nincs átfogó szabályozási keretrendszer. Ilyenkor - az alkotmányos készültség korábbiakban kifejtett elvének szellemében - az egyes rendes jogszabályok szakaszai szolgálnak a kivételes állapot kezelésének alapjául, azt azonban számos olyan elv is befolyásolja, amely nincsen expressis verbis jogszabályi szinten rögzítve. Ezek között említhetô a felelősségi elv, illetve a szubszidiaritás elve. Előbbi értelmében az egyes hatóságok kötelesek azon tevékenységeiket ellátni krízishelyzetben, amelyekért rendes körülmények között is felelősek. Utóbbi alapján pedig a társadalmi élet különböző zavarait ott kell kezelni, ahol bekövetkeztek, és azoknak, akiket érint. ${ }^{59}$

Ugyan a hadiállapotról szóló fejezete nem alkalmazható, azonban így is tartalmaz a Kormányzati tv. olyan rendelkezéseket, amelyek egy estleges - háborúhoz nem köthető - krízishelyzet elhárítása esetén is biztosítják a minél gyorsabb és hatékonyabb eljárás lehetôségét. Ezek elsősorban a parlament müködésének folyamatosságára és a kormány jogalkotási tevékenységére vonatkoznak. Előbbit biztosítják a parlament megválasztására és megalakulására vonatkozó szakaszok, illetve annak lehetősége, hogy ülésének biztonsága és szabadsága érdekében Stockholmtól eltérő helyre hívják össze a parlamentet. ${ }^{\circ}{ }^{\circ}$ Utóbbi kapcsán pedig rögzíti a Kormányzati tv., hogy a kormány egyrészt rendelkezik saját jogalkotó hatáskörrel, másrészt törvényi felhatalmazásra meghatározott ügyek vonatkozásában rendeletet bocsáthat ki, amelyet a parlament döntése alapján felülvizsgálat céljából köteles neki benyújtani. A felhatalmazással együtt a kormány megkaphatja a lehetőséget arra is, hogy az adott kérdésben a szabályok kiadásának jogát közigazgatási hatóságra vagy helyi önkormányzatra ruházza át. ${ }^{61}$

E helyütt érdemes megemlíteni a svéd közigazgatási modell - a koronavírus-járvány kapcsán is elötérbe kerülő - sajátosságát, miszerint a központi közigazgatás szervezetrend-

58 Ortwein, 2003, 408-410. o.

59 Ericson-Wilske, 2020, 1089-1090. o.

60 Kormányzati tv. 3. fejezet 10-11. cikk; 4. fejezet 1. cikk.

61 Kormányzati tv. 8. fejezet 3-8., 10. cikk. 
szerére nagyfokú decentralizáció jellemző, és a minisztériumok tevékenysége a szakpolitikák kidolgozásában merül ki, a közigazgatási feladatok jelentős részét pedig kormányzati ügynökségek látják el. ${ }^{62}$ Ezek ugyan a minisztériumoknak vagy a parlamentnek alárendelten múködnek, ám nagyfokú önállósággal bírnak, a központi kormányzat irányítási jogköre kizárólag abban nyilvánul meg, hogy meghatározza múködésük céljait, elveit, kinevezi a vezetőket, ellenőrzi az elért eredményeket, de egyedi ügyek elintézésére már nem utasíthatja azokat. ${ }^{63} \mathrm{~A}$ kormány tehát irányít, vezet, befolyásol és szabályoz, azonban szoros értelemben vett közigazgatási hatáskört nem gyakorol. ${ }^{64}$ Így a kormánynak kivételes állapot idején sincs joga a kormányzati ügynökségek irányítására, szerepe az általános intézkedésekre és a koordinálásra terjed ki, és így az ügynökségek végzik az operatív tevékenységet. ${ }^{65}$ A válságkezelési tevékenységek összehangolása, az egyes kormányhivatalok és kormányzati ügynökségek közötti információcsere biztosítása érdekében hozták létre az évente legalább két alkalommal ülésező Válságkezelő Testületet (Kansliet för krishantering), amelynek elnöke a belügyminiszter, tagjai pedig az országos rendőrfőkapitány, a Svéd Nemzetbiztonsági Szolgálat (Säkerhetspolisen) vezetője, a svéd fegyveres erők (Affärsverket svenska kraftnät) föparancsnoka, valamint a Svéd Polgári Készenléti Ügynökség, az Országos Egészségügyi és Népjóléti Testület, a Posta- és Távközlési Ügynökség és a Svéd Sugárbiztonsági Ügynökség képviselői.

Fontos kérdés, hogy - szemben a háborúéval - a békeidejú kivételes helyzet, illetve válság fogalma egyértelmúen körülhatárolható-e. A jogirodalomban és a jogalkotási munka során is vita alakult ki ennek meghatározásáról, amely során azt a normálistól eltérő, váratlanul bekövetkező, alapvetô és kiemelt fontosságú értékeket fenyegető, gyors és központosított reakciót igényló szituációként írták körül. ${ }^{66}$ Jogszabályi szinten ez a - fentiekben már említett - Rendkívüli események tv.-ben jelenik meg, amely rögzíti, hogy rendkívülinek a rendestől eltérô, társadalmi funkciók súlyos zavarával vagy annak kockázatával járó, sürgős intézkedést igénylő esemény számít. ${ }^{67} \mathrm{Az}$ önkormányzatok - amelyek vonatkozásában szintén tetten érhető a jelentős decentralizáció ${ }^{8}$ - és a régiók kötelesek az esetlegesen bekövetkező ilyen eseményekre és azok hatására vonatkozó elemző tevékenységet folytatni, felkészítő oktatást biztosítani és a különböző önkormányzati szervek együttmúködését előmozdítani, tervezési és felkészülési munkálataikat összehangolni. ${ }^{69}$ Emellett a településeken és a régiókban válságkezelő testületet (Krisledningsnämnd) kell felállítani a rendkívüli események kezelésére. A testület hivatalba lépésének lehetőségéről annak elnöke dönt. Sürgős esetekben,

62 Berkes, 2018, 57. o.

63 Denti, 2007.

64 Tamás, 2011, 561. o.; Kormányzati tv. 12. fejezet 2. cikk.

65 Jonsson Cornell-Salminen, 2018, 226-227. o.

66 SOU 2008:61. 62-64. o.

67 Rendkívüli események tv. 1. fejezet 4. \$.

68 Kormányzati tv. 14. fejezet 2. cikk.

69 Rendkívüli események tv. 2. fejezet 1. \$, 7-8. \$. 
amikor a testületi döntés jelentős késedelemmel járna, az elnök jogosult a testület nevében - annak mihamarabbi értesítésével - eljárni. Amennyiben a válságkezelő testület szükségesnek ítéli, az önkormányzat vagy a régió más testületeinek tevékenységét - a rendkívüli esemény jellegére és mértékére tekintettel - részben vagy egészben saját hatáskörébe vonhatja. Abban az esetben, ha a rendkívüli esemény már nem áll fenn, az önkormányzat, illetve a régió megszüntetheti a válságkezelő testület tevékenységét. ${ }^{70} \mathrm{~A}$ kormányzati hatóságok rendkívüli események vonatkozásában fennálló kötelezettségeit is rendelet rögzíti, mellékletben felsorolva azokat, amelyek kiemelt felelősséggel tartoznak, ennek keretében pedig - többek között - együttmúködnek a megyei igazgatóságokkal, más állami hatóságokkal, a régiókkal és az önkormányzatokkal, értékelik a nemzetközi kooperáció lehetőségét, valamint mérlegelik a kutatási és fejlesztési tevékenységek szükségességét. ${ }^{71} \mathrm{Az}$ ügynökségek saját maguk és a társadalom rendkívüli eseményekre való felkészítése érdekében folyamatosan vizsgálják, hogy saját hatáskörükön belül van-e olyan kockázat, amely müködésüket rendkívüli események idején veszélyeztetheti. Ennek során kiemelt figyelmet fordítanak a váratlanul felmerülő, a komoly fenyegetést jelentő, illetve sürgős döntéseket és együttmúködést igénylő helyzetekre, valamint a legszükségesebb társadalmi funkciók fenntarthatóságának kérdésére. ${ }^{72}$ Hasonlóan a régiókhoz és önkormányzatokhoz, tájékoztatási kötelezettségük van a kormány irányában az események alakulása, a rendelkezésre álló erőforrások, továbbá a tervezett és megvalósított intézkedések vonatkozásában. ${ }^{73}$

A békeidejû kivételes szituációk kapcsán relevanciával bír az elektromos készenléti törvény ${ }^{74}$ és a polgári védelmi törvény ${ }^{75}$ is. Előbbi a villamosenergia-ágazat rendkívüli eseményeihez kapcsolódó készenléti és válságkezelési intézkedéseket, utóbbi pedig az emberi élet és egészség biztosítására, valamint a vagyon és környezet védelmére irányuló rendelkezéseket rögzíti. ${ }^{76} \mathrm{~A}$ polgári védelmi törvény az önkormányzatok és az állam kötelezettsége mellett az egyének felelősségét is szabályozza, rögzítve azt, hogy aki emberek életét veszélyeztető, illetve az egészségre vagy a környezetre kockázatot jelentő eseményről tudomást szerez, lehetősége szerint köteles az érintett személyt vagy személyeket figyelmeztetni és szükség esetén segítséget hívni. ${ }^{77}$ Azon létesítmények tulajdonosa pedig, ahol az emberekre vagy a környezetre nézve súlyos károkat okozó balesetek veszélyével járó tevékenységet folytatnak, köteles egyfajta válsághelyzeti készültségről gondoskodni. ${ }^{78} \mathrm{Az}$ egyének ez irányú kötelezettségének betartásához az önkormányzat tanácsadás és tájékoztatás útján köteles

70 Rendkívüli események tv. 2. fejezet 2-6. \$.

71 Válság r. 10. \$.

72 Válság r. 8. \$.

73 Válság r. 13. \$.

74 Elberedskapslag (1997:288) (a továbbiakban: Elektromos készenléti tv.).

75 Lag (2003:778) om skydd mot olyckor (a továbbiakban: Pvtv.).

76 Elektromos készenléti tv. 1-4. \$; Pvtv. 1. fejezet 1. \$.

77 Pvtv. 2. fejezet 1. \$.

78 Pvtv. 2. fejezet 4. $\$$. 
segítséget nyújtani. Emellett az önkormányzat maga is köteles megelőző intézkedéseket hozni, amelyek vonatkozásában cselekvési programmal kell rendelkeznie. Abban fel kell tüntetni a megelőző tevékenység célját, az esetleges kockázatokat és az intézkedések szervezésének leírását. ${ }^{79} \mathrm{~A}$ válsághelyzet kezelését követően az önkormányzat köteles biztosítani az esemény okai, lefolyása és a végrehajtott múvelet észszerű tisztázása érdekében annak kivizsgálását. ${ }^{80} \mathrm{Az}$ önkormányzat rendkívüli helyzetek kezelésére irányuló feladatait annak egy vagy több bizottsága is elláthatja, de lehetőség van arra is, hogy azokat részben vagy egészben másik önkormányzat lássa el. ${ }^{81} \mathrm{~A}$ törvény az állam hegyi, légi, tengeri és környezetvédelmi, valamint radioaktív anyagok kibocsátásakor eljáró mentőszolgálat felállításával kapcsolatos kötelezettségéról rendelkezik, ${ }^{82}$ valamint rögzíti, hogy a kormány a polgári védelmi szempontok figyelembevételével további szabályokat adhat ki az élet, az egészség és a környezet védelmére vonatkozóan. A polgári védelem és a rendkívüli események kezelése kapcsán ki kell emelni a Svéd Polgári Készenléti Ügynökséget mint a társadalom válsághelyzetekre való felkészüléséért felelős kormányzati ügynökséget. Ennek feladata, hogy mindenfajta kivételes helyzet során ellássa a szektorokon átnyúló és kormányzati szintú koordinációs, a megelőzéssel és a felkészüléssel kapcsolatos feladatokat, valamint a válsághelyzet kezelésére megfelelő intézkedéseket hozzon. Ezen túlmenően különös figyelmet fordít a tájékoztatásra és a figyelemfelhívásra, ennek részeként tréningeket, továbbképzéseket is szervez köztestületeknek, szervezeteknek és magánszemélyeknek, valamint programot indítottak annak bemutatására, hogy a lakosság milyen, a mindennapjaikat érintő háborús vagy válsághelyzetben találhatja magát. Az erre való felkészülés támogatása érdekében pedig - a program keretében - minden háztartásba eljuttattak egy Ha krízis vagy háború jön ${ }^{83}$ címú kiadványt.

Annak ellenére, hogy a svéd szabályozás és a jogirodalom hangsúlyozza a rendes jogrend szerinti eljárást háborúhoz nem köthetô rendkívüli körülmények esetén, és - sok más állammal szemben - nem biztosítja ilyenkor különleges jogrendi szabályok útján a végrehajtó hatalom rendeleti kormányzásának lehetőségét, ${ }^{84}$ mégis kialakult egyfajta - a kormány és miniszterei intézkedéseit érintő - szükségállapoti gyakorlat. Az alkotmányos keretektől eltérő kivételes eljárás az 1970-es években bekövetkező három terrorcselekmény nyomán alakult

79 Pvtv. 3. fejezet 1-3. \$.

80 Pvtv. 3. fejezet 10. $\$$.

81 Pvtv. 3. fejezet 11-12. \$.

82 Pvtv. 4. fejezet.

83 Om krisen eller kriget kommer. Elérhető: www.dinsakerhet.se/siteassets/dinsakerhet.se/broschyren-omkrisen-eller-kriget-kommer/om-krisen-eller-kriget-kommer_a5_uppslag_msbi186.pdf (Letöltve: 2020. november 30.).

84 Jonsson Cornell-Salminen, 2018, 233-234. o. 
ki. ${ }^{85}$ Mindhárom esetben tehát az alkotmányos keretek betartását mellőzve, megfelelő jogi alap nélkül járt el a kormány, ám az Alkotmányjogi Bizottság - amely jogosult megvizsgálni, hogy a kormány és a miniszterek miként kezelik a kormányzati ügyeket, a meghozott döntések összhangban vannak-e az alkotmánnyal ${ }^{86}$ - felülvizsgálata során mindhárom esetben megállapította a szükséghelyzet fennállását, így igazoltnak látta a kormány fellépését. Az Alkotmányjogi Bizottság a Bulltofta-dráma kapcsán jelentésében úgy fogalmazott, hogy bár szigorúan véve a kormány egyértelmúen nem tartotta be az alkotmányos szabályrendszert, ám tekintettel a fenyegető helyzetre és az idő rövidségére, a kormány a szükségállapoti helyzetet helyesen mérte fel, így nem emelt kifogást az intézkedésekkel szemben. A Norrmalmstorg-ügy felülvizsgálata során - ahol a kormány eljárása mellett a rendőri vezetés is értékelésre került - az Alkotmányjogi Bizottság a Bulltofta-drámára visszautalva állapította meg a szükséghelyzetet. ${ }^{87}$ Az Alkotmányjogi Bizottság mindkét eset kapcsán és a Kormányzati tv. előkészítése során is javaslatot tett a kormány rendkívüli helyzetben való fellépésére vonatkozó különleges jogrendi szabályok alkotmányos szintű rögzítésére. Ennek fényében különösen érdekes, hogy máig nem került sor szükségállapoti kategória létrehozására. Ez leginkább azzal magyarázható, hogy míg háború idején egyértelmû, békeidejû́ szükségállapot során problémás a rendes, törvényeken alapuló jogrendtől való eltérés igazolhatósága. ${ }^{88}$

Mindezek alapján a szükségállapoti kategória jellegének meghatározása igen problémás, hiszen jogszabályi szinten nincs rögzítve, ugyanakkor létezése elfogadott. Nem egyértelmú, hogy alkotmányos elvnek minősül-e, vagy csak eseti kivételnek kell tekinteni. Ha alkotmányos elvként fogadjuk el, komoly problémákat vet fel például a kormányzati ügynökségek függetlensége és az eljáró tisztviselők büntetőjogi felelőssége kapcsán. ${ }^{89}$ Aggályos az is, hogy az eljárás során ugyanaz a hatóság - a kormány - határozza meg formalizált eljárás nélkül a szükségállapot fennállását, majd ő maga gyakorol kivételes hatalmat, mindezt pedig csak utólag (és inkább politikai jelleggel) vizsgálják felül. Illetve már az Alkotmányjogi Bizottság errôl szóló, kvázi precedenst teremtő döntései is régiek. ${ }^{\circ}$ És bár az elmúlt években - egészen

85 Az első, 1972-es Bulltofta-dráma során három jugoszláv állampolgárságú férfi eltérített egy belföldi repülőgépjáratot, az utasok életeért cserébe váltságdijat, illetve hét horvát nemzetiségú, Svédországban fogva tartott személy szabadon bocsátását követelték. A kormány a követeléseknek eleget téve Bulltoftába szállította, majd elengedte a megjelölt személyeket, illetve kifizette a kért váltságdíjat. Az 1973 augusztusában bekövetkezett Norrmalmstorg-ügyben a kormány újfent túllépte hatáskörét, amikor egy fegyveres rablás során túszokat ejtő terrorista követelésére odaszállították és beengedték a bankhelyiségbe a korábban elítélt Clark Olofssont. A harmadik eset pedig a Vörös Hadsereg Frakció hat tagjához köthető, akik 1975 áprilisában elfoglalták a stockholmi nyugatnémet nagykövetséget, ennek során megöltek két túszt, és felrobbantották a nagykövetség épületének egy részét. A terroristákat elfogták és kiutasították, ám egyikük - sebesülései miatt - kórházi kezelésre szorult, és csak ezt követően utasította ki ôt a kormány, amelyre a hatályos jogszabályok szerint az nem volt jogosult.

86 Kormányzati tv. 13. fejezet 1-2. cikk.

87 Jonsson Cornell-Salminen, 2018, 229-230. o.; Hirschfeldt, 2020, 1152-1153. o.; Ericson-Wilske, 2020, 1088. o.; SOU 2008:61. 81-83. o.

88 Hirschfeldt, 2020, 1152-1153. o.

89 Jonsson Cornell-Salminen, 2018, 231-233. o.

90 Jonsson Cornell-Salminen, 2018, 234-235. o. 
a koronavírus-járvány megjelenéséig - nem következett be komoly, alkotmányjogi relevanciával bíró békeidejû́ kivételes állapot, a különleges jogrendi szabályozás kibővitése újra és újra felmerül. Legutóbb 2008-ban tettek javaslatot a Kormányzati tv. háborús fejezetének kibővitésére, amellyel annak címe Háború, háborús veszély és veszélyhelyzetre (Krig, krigsfara och nödsituationer) módosult volna. A javaslat rögzítette volna, hogy olyan veszélyhelyzetek kezelése érdekében, amelyek az emberi életet, a környezetet, illetve a vagyont károsítják vagy veszélyeztetik, a kormány rendeletet bocsáthat ki. Amennyiben a késedelem komoly károkat okozna, olyan tárgyköröket is rendeleti úton szabályozhat, amelyek egyébként törvényi szintre tartoznak. A rendeleti kormányzásnak azonban komoly korlátait határozta meg a javaslat. Egyrészt az nem érintheti az alaptörvényeket, valamint a parlamentről szóló és a parlamenti választásokról szóló törvényeket sem, másrészt a rendeleteket a lehető leghamarabb a parlament elé kell terjeszteni, ugyanis azok tizenkét nappal kihirdetésüket követően hatályukat vesztik, így a rendelkezések továbbéléséről törvényben való megerősítésükkel a parlament dönthet..$^{91} \mathrm{~A}$ kormányt békeidőben rendeleti kormányzási hatáskörrel felruházó javaslatot végül azonban a komoly parlamenti kontrollfunkció ellenére sem fogadták el.

A békeidőben bekövetkező kivételes szituációk svédországi kezelése kapcsán tehát egyrészt az alkotmányos felkészültség elve, másrészt pedig a törvényileg nem szabályozott szükségállapot gyakorlata irányadó. Előbbi kapcsán leginkább a jogszabályi széttagoltság, illetve töredezettség, valamint az problematikus, hogy a parlamentnek nincs jelentős szerepe, a jogszabályok nem biztosítanak számára kiterjesztett felügyeleti jogkört. ${ }^{92}$ Utóbbi vonatkozásában pedig az állapítható meg, hogy - szabályozás hiányában - kizárólag stabil parlamenti bizalom és politikai konszenzus idején múködőképes. ${ }^{93}$

\section{Az alapjogok korlátozására vonatkozó szabályok különleges jogrend idején}

A sajátos szerkezetú svéd alkotmány két alaptörvénye, a sajtószabadságról szóló, illetve a véleménynyilvánítás szabadságáról szóló törvény értelemszerúen a címben megjelölt, illetve az azokhoz kapcsolódó alapjogokról rendelkezik, kitérve azok korlátozásának lehetőségére. Mindkettő rögzíti, hogy az abban foglalt jogosultságok kizárólag az alaptörvény rendelkezései alapján korlátozhatók. ${ }^{94} \mathrm{~A}$ sajtószabadságról szóló törvény meghatározza a sajtószabadság határait, így például lehetővé teszi bizonyos reklámok tilalmát, valamint az olyan személyes adatok, mint az etnikai hovatartozás, politikai vélemény, nemi identitás

91 SOU 2008:125. 1. rész 510. és 521. o.; Hirschfeldt, 2020, 1153-1155. o.

92 Cameron-Jonsson Cornell, 2020, 1178. o.; Jonsson Cornell, 2020, 380-381. o.

93 Jonsson Cornell-Salminen, 2018, 228-231. o.

94 Sajtószab. tv. 1. fejezet 7. \$; Vélemény. tv. 10. \$. 
vagy egészségi állapot közzétételét tiltó jogszabályok elfogadását.95 Az információszabadság részét képező nyilvános dokumentumokhoz való hozzáférés kizárólag törvény által és csak abban az esetben korlátozható, ha azt az állam biztonsága vagy nemzetközi kapcsolatai, a központi költségvetési politika, a monetáris politika vagy más közgazdasági érdek, a hatóságok felügyeleti tevékenysége, bứncselekmények megelőzése vagy felderítése, az egyének személyes vagy pénzügyi körülményeinek védelme, illetve az állat- és növényfajok megőrzése azt megköveteli. ${ }^{96} \mathrm{~A}$ véleménynyilvánítás szabadságáról szóló törvény azonban az egyes alapjogok korlátozása kapcsán a Kormányzati tv.-re utal. A Kormányzati tv. ugyanis 1974-es hatálybalépése óta önálló fejezetben szabályozza az alapvető jogok és szabadságok tárgykörét. A fejezet - az érintett alapjogoknál utalva a két másik alaptörvényre - rögzíti a véleménynyilvánításhoz való jog különböző megnyilvánulásait, a testi integritáshoz való jogot, a mozgásszabadságot, a jogbiztonságot, a diszkrimináció tilalmát, a szakszervezeti jogot, a tulajdonhoz való jogot, a szerzői jogot, a vállalkozás szabadságát, illetve az oktatáshoz és kutatáshoz való jogot.

A fejezet utolsó alfejezete az alapvető jogok és szabadságok korlátozásának lehetőségéről szól. Az alfejezet első szakasza rögzíti, hogy melyek azok a jogok és szabadságok, amelyeket ez egyáltalán érinthet. Ez alapján - kizárólag törvényi úton - korlátozható a véleménynyilvánítási, mozgás-, gyülekezési, egyesülési és információs szabadság, a testi integritáshoz, illetve a nyilvános bírósági eljáráshoz való jog. ${ }^{97} \mathrm{Az}$ alapjogok korlátozásának célja és kiterjedése vonatkozásában a Kormányzati tv. általános keretszabályként rögzíti, hogy arra csak egy demokratikus társadalomban elfogadható okból, a cél eléréséhez szükséges mértékben, azzal arányosan - a vélemény kialakításának szabadságát mint a demokrácia egyik alapintézményét nem veszélyeztetve - kerülhet sor. Nincs helye korlátozásnak pusztán politikai, vallási, kulturális vagy más hasonló okból..$^{8}$ Egyes alapvető jogok vonatkozásában konkrétan megjelöli azokat az értékeket, amelyek érvényre juttatása a szabadságok szúkítésének alapjául szolgálhat. Így a véleménynyilvánítási és az információs szabadság a Svéd Királyság biztonsága, a nemzeti árukínálat, a közrend és közbiztonság, a magánszemély sérthetetlensége, a magánélet szentsége és a bưnüldözés eredményessége, valamint egyéb különösen fontos okból korlátozható. A véleménynyilvánítási szabadság vonatkozásában a kereskedelmi tevékenységet is megjelöli az alaptörvény. Fontos garanciális rendelkezés, hogy a korlátozások bevezetése során is különös figyelmet kell fordítani a véleménynyilvánítási és az információs szabadság politikai, vallási, szakmai, tudományos és kulturális ügyekben való lehető legszélesebb körủ érvényesülésére.99 A gyülekezési jog és a tüntetés szabadsága a közrend fenntartása, a lakosság gyülekezés vagy tüntetés alatti biztonsága, a királyság biztonsága,

95 Sajtószab.tv. 1. fejezet 11-14. \$.

96 Sajtószab.tv. 2. fejezet 1. \$.

97 Kormányzati tv. 2. fejezet 20. cikk.

98 Kormányzati tv. 2. fejezet 21. cikk.

99 Kormányzati tv. 2. fejezet 23. cikk. 
illetve a közlekedés érdekében, valamint járványveszély esetén, az egyesülési szabadság pedig kizárólag a lakosság valamely fajú, bőrszínú vagy etnikai származású csoportjára fenyegetést jelentő katonai vagy félkatonai jellegû szervezet vonatkozásában korlátozható. ${ }^{100}$

A Kormányzati tv. második fejezete átfogóan rögzíti az alapvető jogok és szabadságok, illetve azok korlátozásának kérdéskörét. Utóbbi kapcsán felmerülő kritika, hogy arra széles körben, minősített többséget sem igénylő törvények által nyílik lehetőség. ${ }^{101}$ Szúk keretek között ugyan, de a parlamenti képviselőknek lehetőségük van az alapjogok korlátozásának megakadályozására. Az alaptörvény rendelkezése értelmében tíz képviselő kérelmére az elkészített törvénytervezet, törvénymódosítási vagy hatályon kívül helyezési javaslat tárgyalását annak beterjesztésétől számított tizenkét hónapra el kell halasztani. Ilyenkor a parlament a kérdéses javaslatot a leadott szavazatok öthatodos többségével fogadhatja el. Nincs meg ez a lehetőségük a képviselőknek a törvények időbeli hatályát két évnél nem hosszabb időre meghosszabbító, valamint meghatározott tárgyköröket szabályozó javaslatok esetében. Utóbbiak körébe tartozik a közszolgálat vagy hivatalos feladat teljesítése során megismert, illetve a sajtószabadságról szóló törvény alapján titkosnak minősülő ügyek nyilvánosságra hozatalának tilalma, a házkutatás és ahhoz hasonló intézmények, valamint a büntetőjogi szabadságmegvonás. A halasztási eljárás alkalmazhatóságát az egyes javaslatok vonatkozásában a parlament nevében az Alkotmányjogi Bizottság vizsgálja. ${ }^{102}$

A Kormányzati tv. alapjogi fejezete nem tartalmaz különleges jogrend idején alkalmazandó, alapvető jogok korlátozására vonatkozó rendelkezéseket, és az alaptörvény hadiállapotról szóló része is csak egyetlen idevágó szakaszt tartalmaz. Ennek értelmében a korlátozó javaslatok tárgyalásának fentiekben kifejtett elhalasztására nincs lehetőség háború, illetve háborús veszély idején. ${ }^{103}$ Így az alapvető jogok korlátozása kapcsán a rendes jogszabályok (a Kormányzati tv. második fejezete) alkalmazandók kivételes körülmények során is. Kivételt képeznek ezalól a közrendről szóló törvény ${ }^{104}$ egyes rendelkezései. Az ugyanis kimondja, hogy abban az esetben, ha Svédország háborúban áll vagy háborús veszély fenyegeti, illetve ha az egy járvány megelőzése, valamint leküzdése érdekében szükséges, a kormány rendeletével megtilthatja nyilvános összejövetelek és rendezvények megtartását, illetve a járványhelyzet kezelése során felhatalmazást adhat a megyei igazgatóságoknak a gyülekezési jog korlátozása kapcsán. ${ }^{105} \mathrm{Az}$ ezen tilalom ellenére megtartott nyilvános összejöveteleket és rendezvényeket feloszlathatják, a szervezésben részt vevő személyeket pedig akár szabadságvesztéssel is sújthatják. ${ }^{106}$

100 Kormányzati tv. 2. fejezet 24. cikk.

101 Nergelius, 2019, 331. o.

102 Kormányzati tv. 2. fejezet 22. cikk.

103 Kormányzati tv. 15. fejezet 7. cikk.

104 Ordningslag (1993: 1617) (a továbbiakban: Közrendi tv.).

105 Közrendi tv. 15. \$.

106 Közrendi tv. 22. és 29. \$. 
Említésre érdemes továbbá, hogy a polgári védelemről szóló törvény is tartalmaz jogkorlátozó rendelkezéseket, elsősorban a tulajdonjog sérelme vonatkozásában. A polgári védelmi tevékenység során ugyanis - ha az az emberi élet, az egészség, a környezet, illetve a vagyon megóvása érdekében szükséges - a mentési tevékenység vezetője beavatkozhat mások tulajdonjogi viszonyaiba, kiüríthet területeket, felhasználhat vagy akár meg is semmisíthet ingatlanokat, azonban minden, mások jogát korlátozó döntéséről annak indokát megjelölve köteles írásban jelentést tenni. ${ }^{107}$

\section{A koronavírus-járvány svédországi kezelése}

Az egészségügyi válsághelyzetek kezelése kapcsán - a korábbiakban bemutatott törvények és rendeletek mellett - releváns jogszabály a betegségek terjedésének megakadályozására szolgáló intézkedéseket rögzítô, a fertőzések elleni védekezésról szóló törvény (a továbbiakban: Járványügyi tv. ${ }^{108}$ és az annak egyes részletszabályait tartalmazó rendelet. ${ }^{109}$ A törvény a fertőző betegségeken belül - amely kifejezés valamennyi, az emberi egészségre veszélyt jelentő, emberek között terjedő betegséget felölel - megkülönböztet általános és társadalomra veszélyes betegségeket. Előbbi kategóriába olyan fertőző betegségek tartoznak, amelyek hosszas megbetegedéssel, súlyos tünetekkel vagy akár életveszéllyel, illetve más komoly következményekkel járnak, és terjedésük a fertőzött személyekre irányuló intézkedések révén megakadályozható. Utóbbi kategóriába pedig azok a társadalmi funkciók súlyos zavarával vagy annak közvetlen kockázatával járó általános veszélyes betegségek tartoznak, amelyek rendkívüli intézkedéseket igényelnek. Az e két fogalom alá tartozó betegségeket a Járványügyi tv. mellékletében sorolja fel. ${ }^{110} \mathrm{~A}$ járványügyi tevékenység nemzeti szintű koordinációjáért a közegészségügyi kérdésekkel foglalkozó, a lakosság egészségügyi fenyegetésektől való megóvásáért munkálkodó kormányzati hatóság, a Közegészségügyi Ügynökség (Folkhälsomyndigheten) tartozik felelősséggel. ${ }^{111} \mathrm{~A}$ törvény rendelkezéseiből nem következő intézkedések biztosítása a régiók hatáskörébe tartozik. ${ }^{112} \mathrm{~A}$ Járványügyi tv. az esetek kivizsgálásáról szóló fejezetében rögzít bizonyos, a fertőzések elleni védekezést szolgáló rendkívüli intézkedéseket. Ennek értelmében ha egy Svédországba érkező személyről okkal feltételezhető, hogy a társadalomra veszélyes betegséggel fertőződött meg, a regionális szinten kinevezett járványügyi orvos ${ }^{113}$ döntésére ôt és a vele együtt utazókat ellenőrzésnek kell alávetni. Ugyancsak a járványügyi orvos a társadalomra veszélyes betegség elterjedésének

107 Pvtv. 6. fejezet 2. és 6. \$.

108 Smittskyddslag (2004:168) (a továbbiakban: Járványügyi tv.).

109 Smittskyddsförordning (2004:255).

110 Járványügyi tv. 1. fejezet 3.\$.

111 Járványügyi tv. 1. fejezet 7. $\$$.

112 Járványügyi tv. 1. fejezet 8. \$.

113 Járványügyi tv. 1. fejezet 9. \$. 
veszélye esetén az annak kitett személyt - meghatározott épület elhagyásának tilalmával járó - karanténba helyezheti. Abban az esetben viszont, ha a társadalomra veszélyes betegség egy meghatározott földrajzi területhez kapcsolódik, ott terjedt el, a szükséges intézkedéseket - az országba beérkező személyek egészségügyi ellenőrzését, a fertőzéssel érintett terület lezárását - a Közegészségügyi Ügynökség hozza meg. ${ }^{114} \mathrm{Az}$ általános veszélyes betegségek terjedése megelőzése érdekében - meghatározott tevékenységeket érintő - egyedi magatartási szabályokról dönthet a kezelőorvos. ${ }^{115} \mathrm{~A}$ járványhelyzetek kezelése kapcsán a Járványügyi tv. bizonyos kivételes jellegú hatáskörökkel ruházza fel a kormányt. Ez alapján - amennyiben a parlament nem dönt a Járványügyi tv. mellékleteinek módosításáról - a kormány dönthet az általános és a társadalomra veszélyes betegségekre vonatkozó rendelkezések alkalmazásáról, az erről szóló rendeletet azonban mihamarabb be kell nyújtani felülvizsgálatra a parlamentnek. A törvényben nem rögzített, a járványok elleni védekezéshez szükséges kiegészítő szabályok kibocsátására szintén a kormány - vagy az általa kijelölt hatóság - jogosult. Emellett a Járványügyi tv.-nek megfelelő különleges szabályokat hozhat a fertőzések elleni védekezésről háború, háborús veszély, az ezek következtében eloállt rendkívüli körülmények, valamint a fertőzések ellenőrzésének fenntartását megnehezítő, nemzeti szintú intézkedéseket igénylő békeidejû́ válságok esetén. ${ }^{116}$

A koronavírus-járvány okozta egészségügyi válsághelyzet svédországi kezelését alapjaiban határozták, illetve határozzák meg a Kormányzati tv. egyes rendelkezései, illetve azok hiánya. Utóbbi kapcsán szükséges visszautalnunk arra, hogy a Svéd Királyság vonatkozásában nem beszélhetünk alkotmányos szinten rögzített békeidejú különleges jogrendi szabályozásról, így - ellentétben több más európai állammal - Svédországban rendes jogrendi keretek között zajlik a járványhelyzet elleni küzdelem. ${ }^{117} \mathrm{~A}$ svéd fellépés sajátossága a Kormányzati tv. mozgásszabadságról és a közigazgatási hatóságok függetlenségéről szóló szakaszaiból fakad. Előbbi alapvető jog ugyan törvényben korlátozható, és helyi szinten vagy egyes személyeket érintő módon egészségügyi okból is szúkíthető, ám nincs jogszabályi alapja a szabad mozgáshoz való jog járványhelyzet által indokolt, nemzeti szintû korlátozásának. ${ }^{118} \mathrm{~A}$ közigazgatási hatóságok kormányzattól való - nemzetközi összevetésben egyedülállóo ${ }^{119}$ - függetlensége ${ }^{120}$ ugyancsak megköti a kormány kezét, ${ }^{121}$ az alapján ugyanis a koronavírus-járvány kezelését elsősorban a Közegészségügyi Ügynökség - jogilag kötelező erővel nem bíró - ajánlásai határozzák meg. A járványügyi szakemberek által meghozott - többek között a megfelelő távolság és a higiéniai előírások megtartására, az otthoni munkavég-

114 Járványügyi tv. 3. fejezet 8-10. \$.

115 Járványügyi tv. 4. fejezet 2 . $\$$.

116 Járványügyi tv. 9. fejezet 2-6. \$.

117 Venice Commission, 2020, IV.B.14.

118 Jonung, 2020, 2-3. o.

119 Nergelius, 2018, 300. o.

120 Hirschfeldt, 2020, 1163-1168. o.

121 Mikko, 2020, 7-8. o. 
zésre, a szükségesnek nem minősülő utazások elhalasztására, valamint a magukon a koronavírus tüneteit felfedező, illetve idős személyek otthonmaradására irányulón ${ }^{122}$ - rendelkezésekhez ugyan formálisan nincs kötve a kormány, ám a történeti hagyományok az ajánlások követését kívánják meg. ${ }^{123}$ Központi szinten a Közegészségügyi Ügynökség mellett a Svéd Polgári Készenléti Ügynökség és az Országos Egészségügyi és Népjóléti Testület munkáját kell megemlíteni. ${ }^{124}$ Előbbi a polgári védelmi tevékenységek koordinálásáért, utóbbi pedig - a hatáskörét rögzítő rendelet ${ }^{125}$ értelmében - az egészségügyi és szociális szolgáltatások tudományos és tapasztalaton alapuló elvégzéseeért, a válságra való felkészülést segítő tájékoztatásért, valamint a megfelelő szakértelem válsághelyzet idején való rendelkezésre állásáért ${ }^{126}$ felelős a koronavírus-járvány kezelése során is. A Közegészségügyi Ügynökség tevékenységét rögzítő jogszabály alapján ${ }^{127}$ - az állásfoglalások kibocsátásán túl - az ügynökség koordinálja és ellenőrzi az orvosi ellátásra való felkészültség megtervezését, figyelemmel kíséri és elemzi a fertőző betegségek kialakulását és a védekezés során tapasztaltakat, illetve tájékoztatást nyújt a Külügyminisztérium számára az utazási ajánlásokkal kapcsolatos döntések meghozatalához. ${ }^{128}$ Továbbá említésre érdemes, hogy a kormányzati szereplők közötti, a válságkezeléssel kapcsolatos információáramlás biztosítása érdekében a belügyminiszter - már a járványhelyzet korai szakaszában - összehívta a Válságkezelő Testület rendkívüli ülését.

A Közegészségügyi Ügynökség ajánlásai mellett jogszabályi szintú intézkedésekről is beszélhetünk, amelyek alapját elsősorban a Járványügyi tv. és a Közrendi tv. szolgáltatta. ${ }^{129}$ Elsőként a február 1-jén hatályba lépő, a Járványügyi tv. általános és társadalomra veszélyes betegségekre vonatkozó szabályainak koronavírus-járványra való alkalmazhatóságát kimondó rendeletet ${ }^{130}$ kell megemlíteni, amely alapján egyrészt a megbetegedett személyekkel szemben - a járvány megfékezése érdekében - bizonyos kényszerintézkedések alkalmazhatók, illetve a kormány felhatalmazást kapott a koronavírus elleni küzdelemhez szükséges kiegészító és különleges szabályok kiadására. ${ }^{131}$ Ennek megfelelően több, alapvető jogot is korlátozó rendeletet fogadott el a kormány. Kiemelendő ezek közül a nyilvános összejövetelek és rendezvények tilalmáról szóló, 2020. március 12-én hatályba lépő rendelet, ${ }^{132}$ amely ötszáz fő́ben maximalizálta a nyilvános összejöveteleken és rendezvényeken részt vevő

122 Bentzen, N. et al., 2020, 10. o.

123 Jonung, 2020, 5. o.

124 Ericson-Wilske, 2020, 1093.0.

125 Förordning (2015:284) med instruktion för Socialstyrelsen (a továbbiakban: OENT r.).

126 OENT r. 4 . \$1. pont; 8-9. \$.

127 Förordning (2013:1020) med instruktion för Folkhälsomyndigheten (a továbbiakban: KEÜ r.).

128 KEÜ r. $1-3$. $\$$.

129 Ludvigsson, 2020, 2464. 0.

130 Förordning (2020:20) om att bestämmelserna i smittskyddslagen (2004:168) om allmänfarliga och samhälls-

farliga sjukdomar ska tillämpas på infektion med 2019-nCoV.

131 Ericson-Wilske, 2020, 1080-1081. o.

132 Förordning (2020:114) om förbud mot att hålla allmänna sammankomster och offentliga tillställningar. 
személyek számát. A rendelet későbbi módosításainak köszönhetően ez a szám - meghatározott kivételekkel ${ }^{133}$ - ötven, ${ }^{134}$ majd pedig nyolc ${ }^{135}$ főre csökkent, illetve a megyei igazgatóság felhatalmazhatja az önkormányzatokat és a megyei közigazgatási testületeket, hogy helyi szintú jogszabályokat bocsássanak ki. Szemben a mozgásszabadsággal, a gyülekezési jog járványhelyzet idején való korlátozása alkotmányos és törvényi szinten egyaránt biztosított, köszönhetően a Kormányzati tv. és a Közrendi tv. - korábban bemutatott - rendelkezéseinek. A kormány az oktatási törvény ${ }^{136}$ felhatalmazása ${ }^{137}$ alapján rendeleti úton ${ }^{138}$ teremtette meg az iskolák járványhelyzet-kezelése érdekében történő bezárásának feltételeit, előkészítve - az egyes oktatási tevékenységek felfüggesztését lehetővé tévő - az iskolai tevékenységek békeidejű rendkívüli körülmények során történő ideiglenes megszüntetéséről szóló törvény ${ }^{139}$ elfogadását. A konkrét rendelkezések értelmében az iskolák a tizenhat éves kor alatti gyerekek esetében nyitva maradtak, az idősebb diákok és egyetemisták vonatkozásában pedig online térben folytatódott az oktatás. ${ }^{140}$ A szociális szolgáltatásokról szóló törvény ${ }^{141}$ rendelkezése ${ }^{142}$ nyomán rendeletével ${ }^{143}$ tiltotta meg a kormány az idősotthonok látogatását. Meghozott intézkedéseivel - közzétett stratégiája ${ }^{144}$ értelmében - a kormány célja a koronavírus terjedési ütemének csökkentése, az emberek életének, egészségének és munkahelyének védelme, valamint a társadalomra és az egészségügyre nehezedő nyomás enyhítése.

Az addigi felhatalmazást elégtelennek találva, a kormány gyorsabb és erőteljesebb fellépésének biztosítása érdekében ideiglenes hatállyal módosították a Járványügyi tv.-t. ${ }^{145}$ A három új szakasz elfogadásával egyidejúleg megszavazott különálló törvény ${ }^{146}$ rögzítette, hogy a módosítás 2020. július 1-jén hatályát veszti. Az új rendelkezések kiterjesztették

133 A hatályos szabályozás értelmében a temetéseken részt vevők száma legfeljebb húsz fő lehet, illetve lehetőség van maximum háromszáz személy részvételével zajló nyilvános összejövetelek és rendezvények megtartására, ha a résztvevők között legalább egyméteres távolság végig biztosított.

134 Förordning (2020:162) om ändring i förordningen (2020:114) om förbud mot att hålla allmänna sammankomster och offentliga tillställningar.

135 Förordning (2020:1000) om ändring i förordningen (2020:114) om förbud mot att hålla allmänna sammankomster och offentliga tillställningar.

136 Skollag (2010:800) (a továbbiakban: Oktatási tv.).

137 Oktatási tv. 29. fejezet 29. \$.

138 Förordning (2020:115) om utbildning på skolområdet och annan pedagogisk verksamhet vid spridning av viss smitta.

139 Lag (2020:148) om tillfällig stängning av verksamheter på skolområdet vid extraordinära händelser i fredstid 140 Ludvigsson, 2020, 2465-2467. o.

141 Socialtjänstlag (2001:453) (a továbbiakban: Szoc. tv.).

142 Szoc. tv. 16. fejezet 10. \$.

143 Förordning (2020:163) om tillfälligt förbud mot besök i särskilda boendeformer för äldre för att förhindra spridningen av sjukdomen Covid-19.

144 A svéd kormány koronavírus-járvány kezelésére irányuló stratégiája elérhető: www.regeringen.se/ regeringens-politik/regeringens-arbete-med-coronapandemin/strategi-med-anledning-av-det-nyacoronaviruset/ (Letöltve: 2020. december 15.).

145 Lag (2020:241) om ändring i smittskyddslagen (2004:168).

146 Lag (2020:242) om ändring i smittskyddslagen (2004:168). 
a kormány jogalkotó hatáskörét, rögzítve, hogy ha az a koronavírus-járvány kezelése érdekében szükséges és a parlament nem dönt, a kormány rendeletet alkothat az egyének kötelezettségei, illetve az egyének és a közösség viszonya vonatkozásában. Így ideiglenes intézkedéseket hozhat különösen a gyülekezés, illetve a gyógyszerek és különböző orvosi eszközök kereskedelmének korlátozásáról, a bevásárlóközpontok, szórakozó- és vendéglátóhelyek bezárásáról, valamint egyes jelentős infrastruktúrák múködésének leállításáról. ${ }^{147}$ Emellett rendeleteket bocsáthat ki a gyógyszerek és orvosi eszközök önkormányzatok és régiók közötti kereskedelmének és újraelosztásának összehangolása érdekében. ${ }^{148} \mathrm{~A}$ kormány tehát rendkívüli rendeletalkotási hatáskört kapott, amellyel együtt számos garanciális szabályt is törvénybe foglalt. A már említett ideiglenes hatály mellett rögzítették, hogy a kibocsátott rendeleteket haladéktalanul be kell nyújtani felülvizsgálatra a parlamenthez, amely azt törvénnyel módosíthatja vagy hatályon kívül helyezheti. ${ }^{149} \mathrm{~A}$ parlamenti kontrollfunkció gyakorlását segíti a frakcióvezetőknek a parlament múködésének folytonosságát biztosító döntése, amelynek értelmében - a haditanács intézményére emlékeztető módon - 2020 végéig a parlamenti döntéshozatalban csak 55 képviselő vesz részt. ${ }^{150} \mathrm{~A}$ kormány felhatalmazásának korlátját jelenti az is, hogy a rendeletek nem szúkíthetik azokat az alapvető jogokat és szabadságokat, amelyek a Kormányzati tv. alapján kizárólag törvényi szinten korlátozhatók. ${ }^{151} \mathrm{~A}$ kormány kivételes felhatalmazását rögzítő szakaszok hatályon kívül helyezésével egyidejûleg - a Járványügyi tv. újabb módosításával - a koronavírust felvették az általános és társadalomra veszélyes betegségek közé. ${ }^{152}$

Azzal, hogy a járványhelyzet az ajánlások és a meghozott intézkedések hatására sem mérséklődött, a svéd járványkezelésre is a szigorúbb rendelkezések, illetve a törvényi szintú szabályok váltak jellemzővé. Előbbire a gyülekezési jog egyre jelentősebb korlátozása, utóbbira pedig a vendéglátóhelyeket érintő járványügyi intézkedésekről szóló törvény ${ }^{153}$ szolgál például. E törvény értelmében a vendéglátóhelyek kötelesek müködésüket a koronavírus elleni védekezés jegyében átalakítani, az ezzel kapcsolatos előírások és tilalmak betartását pedig az önkormányzatok környezet- és egészségvédelmi bizottsága ellenőrzi. Decemberi módosítása ${ }^{154}$ következtében az eredetileg 2020. év végéig hatályos törvény egészen 2021 májusáig érvényben marad. Ugyancsak a szigorítások részeként értékelhető az alkoholtermékek forgalmazását este tíz és délelőtt tizenegy óra között megtiltó rendelet ${ }^{155}$ elfogadása.

147 Járványügyi tv. 6a. \$ (1) bekezdés.

148 Járványügyi tv. 6b. \$.

149 Járványügyi tv. 6c. \$.

150 Cameron-Jonsson Cornell, 2020, 1178. o.; Ericson-Wilske, 2020, 1094. o.

151 Jonsson Cornell, 2020, 379. o.

152 Lag (2020:430) om ändring i smittskyddslagen (2004:168).

153 Lag (2020:526) om tillfälliga smittskyddsåtgärder på serveringsställen.

154 Lag (2020:1192) om dels fortsatt giltighet av lagen (2020:526) om tillfälliga smittskyddsåtgärder på serveringsställen, dels ändring i samma lag.

155 Förordning (2020:956) om tillfälligt förbud mot servering av alkohol. 


\section{A különleges jogrend bevezetésével és a járványhelyzet kezelésével kapcsolatos tapasztalatok, jogviták}

A Svéd Királyságban az 1974-es kormányzatról szóló törvény hatálybalépése óta nem került sor sem háború, sem háborús veszély kihirdetésére, így sem a Haditanács, sem pedig a kormány nem gyakorolta még különleges jogrendi jogosultságait. A kormány központi alaptörvényben nem rögzített, alkotmányos kereteken túllépő szükségállapoti gyakorlat keretében történő kivételes hatalomgyakorlása azonban nem példa nélküli. A három - fentiekben bemutatott - precedens jellegú esemény mellett említésre érdemes az 1981-ben zátonyra futott U-137-es - atomfegyverekkel felszerelt - szovjet tengeralattjáró ügye, amelynek kezelését miniszterek egy csoportjára bízták, biztosítva ezzel az eset gyors és következetes megoldását. ${ }^{156}$

A közelmúlt jelentős, közjogi vitát is kiváltó válsághelyzeteként meg kell említeni a 2004 decemberében az Indiai-óceánon bekövetkezett szökőárt, amely ugyan területileg nem érintette Svédországot, de több mint ötszáz svéd állampolgár életét követelte, és ezreket kellett evakuálni. A kormány válságintézkedéseit komoly kritikával illették, leginkább annak késedelmes megindítása és az információáramlás elégtelensége vonatkozásában. A természeti katasztrófa kormányzati kezelésének értékelése céljából 2005 januárjában a kormány független bizottság felállításáról döntött. Utóbbi jelentése ${ }^{157}$ rámutatott, hogy az ehhez hasonló esetekben a kormánynak fel kell ismernie a kialakult helyzetből fakadó fenyegetéseket, a megfelelő intézkedéseket és a jogalkotás szükségességét, valamint gondoskodnia kell a válságkezelés finanszírozásáról és a kielégítő tájékoztatásról, illetve kapcsolatban kell állnia más államokkal az intézkedések összehangolása és a konfliktusok elkerülése érdekében. A bizottság jelentése a szervezeti struktúrát és a hatáskörmegosztást is kifogásolta a válságkezelési szabályozás kapcsán, hozzájárulva ezzel a Válságkezelési Hivatal - eredetileg Miniszterelnöki Hivatalon belüli - létrehozásához. ${ }^{158}$ E természeti katasztrófán kívül Svédország kapcsán nemigen találunk közjogi szempontból releváns válsághelyzetet.

A koronavírus-járvány kapcsán egyelőre nem beszélhetünk jelentős jogesetekről, ami annak fényében nem meglepő, hogy a Svéd Királyság válságkezelése - ellentétben sok más európai országgal - szabályozás helyett ajánlásokra és információkra támaszkodott. ${ }^{159}$ A svéd válságpolitikát elsősorban a korlátozó intézkedések - relatív - hiánya és a koronavírus-járvány következtében elhunytak magas száma miatt érte - jogilag talán kevésbé releváns - kritika. Azonban megemlíthetók az alapjogok korlátozása, a kormány kivételes rendeletalkotása, a korlátozásokat tartalmazó jogszabályok és ajánlások kihirdetése, valamint

156 SOU 2008:61. 83-84. 0.

157 Sverige och tsunamin - granskning och förslag. Expertrapporter från 2005 års katastrofkommission, Stockholm, 2005. Elérhető: www.regeringen.se/49bb3a/contentassets/8627d9339e414175bocef6b33eea2a64/ sverige-och-tsunamin---granskning-och-forslag-expertrapporter (Letöltve: 2020. december 15.).

158 SOU 2008:61. 77-78., 93. o.

159 Hirschfeldt, 2020, 1168-1169. o. 
a kormányzati ügynökségek függetlensége vonatkozásában felmerült problematikus és vitás kérdések.

Az alapvető jogok és szabadságok kormány általi korlátozására a központi alaptörvény rendkívül szúk lehetőséget ad, és mivel annak rendelkezései a koronavírus-járvány kezelése során is irányadók, nem beszélhetünk az alapjogok korlátozása kapcsán olyan vitáról, amely számos más államban tapasztalható. A kormány rendeletei - egyre szigorúbb szabályokat előírva - leginkább a gyülekezési jogot érintették. Ezek alkotmányos és törvényi megalapozottsága azonban nem képezi vita tárgyát, egyedül annak tartalmát érte kritika. A nyilvános események és összejövetelek korlátozása bár összhangban áll a hatályos jogi szabályozással, azonban járványügyi szempontból problematikusnak tekinthető, hogy a különböző kulturális és sporteseményekkel szemben a rendeleti korlátozás sem a tömegközlekedést, sem pedig a bevásárlóközpontokat nem érinti. Emiatt pedig felmerül a Közrendi tv. felülvizsgálata szükségességének kérdése. ${ }^{160}$

A kormány rendeletalkotási jogköre annak ideiglenes jellege, a parlament erős kontrollfunkciója, valamint a kizárólag törvényben korlátozható alapvető jogok érinthetetlensége miatt nem szolgált közjogi viták alapjául, azonban az ennek alapjául szolgáló, a Járványügyi tv. módosításáról szóló törvény elfogadása aggályokat vetett fel. A Törvényalkotási Tanács (Lagrådet) - amely a legfelsőbb bíróság és a legfelsőbb közigazgatási bíróság bíróiból, illetve volt bíróiból álló, a törvényalkotás során véleményező szerepet betöltő testület ${ }^{161}$ - sérelmezte a törvény nem megfelelő előkészítését, és az ennek során elvégzendő konzultációs tevékenység elmulasztását. A Kormányzati tv. nem tartalmaz részletes szabályokat a törvények elfogadása kapcsán, kizárólag ajánlások rendelkeznek az elókészítő munkához szükséges időtartamról, rögzítve, hogy föszabály szerint a konzultációs eljárás nem lehet három hónapnál rövidebb, ám sürgős esetekben kivételt lehet tenni. A Járványügyi tv. módosítása során a kormány a törvényjavaslatot csak korlátozott számú konzultációs testülethez juttatta el, mindössze 24 órás válaszidőt biztosítva számukra. A Törvényalkotási Tanács a rövid határidő mellett a nem megfelelő számú szervvel való egyeztetést is kifogásolta. ${ }^{162}$

Köszönhetően annak, hogy a koronavírus-járvány kezelése érdekében hozott rendeletek sokszor a kihirdetésük ${ }^{163}$ napján léptek hatályba, ám az sokszor késedelmes volt, a jogszabályok megismerhetőségének vitatottsága jogbiztonsági kérdéseket vetett fel. Hasonló probléma merült fel a Közegészségügyi Ügynökség nyomtatott és online formában is közzétett ajánlásai kapcsán is. Az ügynökség weboldalán közzétett ajánlásoknál több esetben hiányzott ugyanis a nyomtatásban való megjelenés dátuma, számos elốrásnál pedig a hatálybalépés utáni időpontot jelöltek meg. Az ehhez hasonló zavarok vezettek oda, hogy egy,

160 Ericson-Wilske, 2020, 1081-1082. o.

161 A Törvényalkotási Tanács szabályait önálló törvény rögzíti: Lag (2003:333) om Lagrådet.

162 Dibb, 2020, 535., 539-540. o.; Jonsson Cornell, 2020, 378-379. o.

163 A jogszabályok és egyéb rendelkezések kihirdetéséről szóló törvény [Lag (1976:633) om kungörande av lagar och andra författningar] értelmében a jogszabályok és egyéb rendelkezések kihirdetésére négy felület áll rendelkezésre, ám főszabályként azokat a Svéd Jogszabálygyưjiteményben (Svensk författningssamling) kell kihirdetni. 
a vendéglátóhelyeken való tartózkodást előíró ajánlást egyes éttermek annak érvényessége elôtt alkalmaztak, amelynek köszönhetően komoly anyagi kár érte őket. ${ }^{164}$

A járványhelyzet hatására megmutatkoztak a svéd közigazgatási modell árnyoldalai is. A kormányzati ügynökségek nagyfokú függetlenségének komoly történelmi előzménye és hagyománya van Svédországban, amely abban is megmutatkozik, hogy bár megvan hozzá a joga, a kormány nem utasítja el a Közegészségügyi Ügynökség ajánlásait. Felmerült ugyanakkor a politikai felelősség kérdése, amelyet ugyan elvileg a kormány visel, ám a gyakorlatban kevéssé valósul meg. ${ }^{165} \mathrm{~A}$ koronavírus-járvány okozta válsághelyzet kapcsán újra felmerült a békeidejû́ rendkívüli szituációk kezelésének alkotmányos szintû szabályozása. ${ }^{166}$

A kritikákra tekintettel a kormány a koronavírus-járvány kezelése érdekében hozott rendelkezések értékelésére - 2020. július 1-jével - bizottságot állított fel. Az úgynevezett Koronabizottság (Coronakommissionen) feladata - az erról szóló irányelv ${ }^{167}$ értelmében - a kormány, az érintett közigazgatási hatóságok, a régiók és az önkormányzatok által a vírus terjedésének korlátozása, valamint hatásának enyhítése érdekében bevezetett intézkedések vizsgálata, illetve nemzetközi összehasonlítás elvégzése. Végső jelentését 2022. február 28-ig kell elkészítenie a bizottságnak; ez idő alatt két másik, köztes jelentést köteles tenni: az elsőt 2020. november 30-ig, a másodikat pedig 2021. október 31-ig. Az első részjelentés ${ }^{168}$ közzétételére végül 2020. december 15-én került sor. A bizottság ebben a járványhelyzet alatti idősgondozásról számol be, a koronavírus idősek körében való nagyfokú terjedésének és az ahhoz kapcsolódó magas halálozási aránynak az okát az idősgondozással foglalkozó intézmények felkészületlenségére, rossz felszereltségére, valamint szerkezeti hibákra vezetve vissza, mindezekért a jelenlegi és korábbi kormányokat téve felelőssé. A bizottság szerint az idősek védelmére irányuló stratégia kudarcot vallott, a strukturális felkészültség hiánya pedig elsősorban a széttagolt szervezetrendszernek, a nem megfelelő jogszabályi keretnek, az orvosi eszközökhöz való hozzáférés akadályoztatottságának, az elkésett és sokszor nem megfelelő döntéshozatalnak, valamint a személyi állomány és a megfelelő munkakörülmények hiányának köszönhetô.

164 Dibb, 2020, 541-542. 0.

165 Ludvigsson, 2020, 2464-2465. o.; Ericson-Wilske, 2020, 1094-1096. 0.; Cameron-Jonsson Cornell, 2020, 1181-1182. 0 .

166 Ericson-Wilske, 2020, 1085. o.

167 Kommittédirektiv (2020:74) Utvärdering av åtgärderna för att hantera utbrottet av det virus som orsakar sjukdomen Covid-19. Elérhető: www.regeringen.se/49f46d/contentassets/593c32df14114d9c81eeba9c96e2 6e41/dir2020_74.pdf (Letöltve: 2020. december 15.).

168 Internationella erfarenheter av Covid-19 i äldreboenden. Underlagsrapport till SOU 2020:80 Äldreomsorgen under pandemin, Stockholm 2020. Elérhető: www.regeringen.se/4af363/contentassets/a8e708fff5e84279bf11ad bdof78fcc1/internationella-erfarenheter-av-Covid-19-i-aldreboenden_webb.pdf (Letöltve: 2020. december 15.). 


\section{5. Összegzés}

Az alkotmányos szintú svéd különleges jogrendi szabályozás kimerül a háború és a háborús veszély kategóriáinak rögzítésében. E helyzetekről ugyan külön fejezetben rendelkezik a Kormányzati tv., ám nem rögzíti azok definícióját. Nem határozza meg, hogy mikor, illetve meddig alkalmazhatók a kivételes jellegú szabályok, ebből következően a kormány döntésén múlik a hadiállapot fennállása, egyedül az ország megszállása képez kivételt, ilyenkor automatikusan a háborús szabályok alkalmazandók. A Kormányzati tv. különleges jogrendi fejezete elsősorban hatásköri rendelkezéseket tartalmaz. Figyelemre méltó, hogy háború, illetve a háborús veszély kihirdetésével egyidejüleg összehívják a parlamentet, és nem ruházzák fel kivételes rendeletalkotási hatáskörrel a kormányt, csak a legvégső esetben. Ehhez azonban szükséges az is, hogy a parlamentet egyfajta szúkített képviseleti szervként kivételesen helyettesítő Haditanács ne tudja feladatait ellátni. Alacsonyabb jogszabályi szinten a hadiállapotra való felkészülés szabályait rögzítő különböző törvények és rendeletek emelhetők ki, amelyek meghatározzák a felelős hatóságok, a régiók és az önkormányzatok feladatait. Rendelet sorolja fel azokat a jogszabályokat is, amelyek háború idején automatikusan alkalmazandók. Elmondható tehát, hogy bár háború és háborús veszély során lehetőség van a különleges jogrendi jogalkotásra, a svéd jogrend jogszabályai széles körben tartalmaznak ilyenkor alkalmazható normákat. Ez hatványozottan igaz a békeidejú kivételes szituációk kapcsán. Ezen utóbbiak vonatkozásában ugyanis nem találunk alkotmányos szintú különleges jogrendi helyzetet, azonban számos törvény és rendelet foglalkozik a rendestől eltérô, társadalmi funkciók súlyos zavarával vagy annak kockázatával járó, sürgős intézkedést igénylő események kezelésével. A svéd megközelités értelmében valamennyi, nem háborúhoz köthető válsághelyzet megoldása rendes jogrend szerint kell hogy történjen. Ennek köszönhető, hogy jogszabályok széles köre tartalmaz rendkívüli események idején alkalmazandó rendelkezéseket, ami a válságkezelési szabályozás széttagoltságához vezet. Inkább tekinthetố különleges jogrendi helyzetnek a sem alkotmányos, sem törvényi szinten nem rendezett szükségállapoti kategória, amely az 1970-es években egymás után rövid időn belül bekövetkezett három terrorcselekmény és annak kezelése hatására kialakult gyakorlat. Ennek során a kormány kivételes hatalomgyakorlására van lehetőség, amely - a jogszabály hiánya mellett - azért rendkívül problematikus, mert egyedül a kormány határozza meg a szülsséghelyzet fennállását, majd gyakorol rendkívüli hatásköröket. Mindezt pedig csak utólag értékeli az Alkotmányjogi Bizottság. Bár a szükségállapoti gyakorlat alkotmányjogi helyzete nem egyértelmú, és az azt megalapozó jelentések is régiek, létezését tényként fogadja el a svéd alkotmányjog-tudomány.

A svéd mellé állítva megállapítható, hogy a magyarországi különleges jogrendi szabályozás jelentősen kiterjedtebb és átfogóbb. A legkézenfekvőbb különbség, hogy Magyarország Alaptörvénye a békeidejú szituációkra is kitérve hat - illetve az Alaptörvény kilencedik módosítása ${ }^{169}$

169 Magyarország Alaptörvényének kilencedik módosításáról szóló T/13647. számú törvényjavaslat. (A módosításról szóló törvényt a kézirat lezárásáig nem hirdették ki a Magyar Közlönyben.). 
értelmében 2023 júliusától három - különleges jogrendi szituációt nevesít, valamennyi vonatkozásában megadva az elrendelésük alapjául szolgáló feltételeket. A svéd háború és háborús veszély kategóriákkal a hatályos Alaptörvény rendkívüli állapoti, megelőző védelmi helyzeti és váratlan támadási kategóriái állíthatók párhuzamba. Utóbbi kettő esetében a Kormányt ruházzák fel rendkívüli hatáskörökkel, míg a svéd háború és háborús veszély idején csak végső esetben kerülhet sor a kormány rendeleti kormányzására. Különbséget jelent, hogy a két magyar szituációt behatárolt idôtartamra lehet kihirdetni, a svéd hadiállapot határideje kapcsán azonban nem találunk rendelkezést. A rendkívüli állapot a tekintetben mutat hasonlóságot, hogy annak elrendelésével szintén egy testületi szervet ruháznak fel rendeletalkotási jogkörrel, azonban a magyar Honvédelmi Tanács a svéd Haditanácsnál szúkebb körú, nem a parlament kvázi szúkebb ülését biztosító szerv. Különbséget jelent az is, hogy ellentétben a svéd királlyal, a magyar államfó jelentős hatáskörrel rendelkezik. Az Alaptörvény módosítása következtében a háborús szituációhoz kapcsolódó különleges jogrendi helyzetek egyetlen kategóriában öltenek testet. A hadiállapot elrendelésének alapjaként explicit módon megjelenik a háború és a háborús veszély fogalma az Alaptörvényben is, ugyanakkor a Honvédelmi Tanács megszüntetésével a Kormány lesz jogosult rendeletet alkotni.

Az alapvető jogok korlátozását a svéd Kormányzai tv. és Magyarország Alaptörvénye hasonlóan szabályozza. Mindkettő rögzíti a korlátozás lehetőségének alapvető feltételeit, kitérve annak elfogadható okára és mértékére, ezen túlmenően pedig további követelményeket támaszt az egyes alapjogok vonatkozásában. A Kormányzati tv. alapjogi fejezete azonban gyakorlatilag változatlanul érvényes háború és háborús szituáció esetén is, míg az Alaptörvény rögzíti a különleges jogrend esetén kivételesen korlátozható alapvető jogok körét. A svéd szabályozásban egyedül a gyülekezési jog képez kivételt, annak háborús szituációban való korlátozására a Közrendi tv. alapján kerülhet sor.

A koronavírus-járvány okozta válsághelyzet svédországi és magyarországi kezelése annak fényében jelentős eltérést mutat, hogy míg hazánkban veszélyhelyzetet rendeltek el, a Svéd Királyságban nem került sor különleges jogrendi helyzet kihirdetésére, azaz a rendes jogrendi szabályok érvényesülnek. A svéd válságkezelést alapvetően a Közegészségügyi Ügynökség ajánlásai határozzák meg, azonban törvényi felhatalmazás alapján ideiglenes jelleggel a svéd kormány is kivételes rendeletalkotási jogkört gyakorolhatott. Ezt azonban jelentősen szúkítette az erős parlamenti kontrollfunkció, valamint az alapvető jogok korlátozásának tilalma. Komoly különbséget jelent, hogy a svéd alkotmányos szabályozás értelmében a mozgásszabadság rendeleti úton való korlátozására nincs lehetőség, így szemben a magyarországi - és több más európai államban is bevezetett - korlátozásokkal, Svédországban nem rendeltek el kijárási tilalmat. Egyedül a gyülekezési jogot érintő szabályozás mutat hasonlóságot, az azt korlátozó rendelkezések mértéke hasonlít - a novemberi szigorítások következtében - leginkább a magyar rendelkezésekhez. 


\begin{tabular}{|c|c|c|c|}
\hline & $\begin{array}{c}\text { Háború és háborús } \\
\text { veszély }\end{array}$ & Rendkívüli események & Szülsségállapot \\
\hline Szabályozás szintje & Alkotmányos & Törvényi & $\begin{array}{l}\text { Nincs jogszabályi } \\
\text { szinten rögzítve }\end{array}$ \\
\hline Alkalmazás alapja & $\begin{array}{l}\text { A kormány } \\
\text { döntése, } \\
\text { megszállás }\end{array}$ & $\begin{array}{l}\text { A rendestől eltérő, tár- } \\
\text { sadalmi funkciók súlyos } \\
\text { zavarával vagy annak koc- } \\
\text { kázatával járó, sürgős intéz- } \\
\text { kedést igényló esemény }\end{array}$ & A kormány döntése \\
\hline Elrendelés & Kormány & \multirow{2}{*}{$\begin{array}{l}\text { Rendes jogrendi jog- } \\
\text { szabályok alkalmazása } \\
\text { (önkormányzatok, régiók, } \\
\text { ügynökségek) }\end{array}$} & \\
\hline Felhatalmazott & $\begin{array}{l}\text { Parlament, Hadi- } \\
\text { tanács, kormány }\end{array}$ & & Kormány \\
\hline Gyakorlati esetek & $\begin{array}{l}\text { Nem hirdették ki } \\
\text { ez idáig. }\end{array}$ & Többször sor került rá. & $\begin{array}{l}\text { Lásd a Békeidejü kivételes } \\
\text { szituációk címú részt. }\end{array}$ \\
\hline
\end{tabular}

21. táblázat

A Svéd Királyság különleges jogrendi szabályainak összegzése

Forrás: a szerzô saját összeállítása

\section{Irodalomjegyzék}

Bentzen, N., Boström, A., Del Monte, M., Odink, I., Prpic, M., Tuominen, M. (2020) States of Emergency in Response to the Coronavirus Crisis: Situation in Certain Member States III. [Online] Elérhető: www.europarl.europa.eu/RegData/etudes/BRIE/2020/651972/EPRS_ BRI(2020)651972_EN.pdf (Letöltve: 2020. december 15.)

BERKES, L. (2018) 'A központi közigazgatás modelljei. Svédország' in Gerencsér, B. Sz. (szerk.) Összehasonlitó és európai uniós közigazgatási jog. 3. kiadás. Budapest: Pázmány Press

Cameron, I., Jonsson Cornell, A. (2020) 'Fredstida kriser i en konstitutionell kontext en komparativ analys och en försiktig framåtblick för Sveriges del', Svensk Juristtidning, 2020/10, 1173-1190. o.

Csink, L. (2017) 'Mikor legyen a jogrend különleges?', Iustum Aequum Salutare, 13(4), 7-16. o.

DENTI, D. (2007) Administrative Law in Sweden and Italy: A Comparison [Online]. Elérhető: www. academia.edu/896258/Administrative_Law_in_Sweden_and_in_Italy_a_comparison (Letöltve: 2020. december 15.)

Dівв, J. (2020) 'Om beredning, kungörelse och ikraftträdande av författningar i kristid', Svensk Juristtidning, 2020/7, 534-545. o.

ERICSON, M., WILSKE, O. (2020) 'Covid-19 i Sverige - rättsliga perspektiv på krisberedskap och de åtgärder som vidtagits för att hantera pandemin', Svensk Juristtidning, 2020/10, 1080-1097. 0. 
Hansson, P., Persson, M. (2020) 'Sweden: COVID-19', European State Aid Law Quarterly, 19(1), 97-98. o.

HiRSCHFELDT, J. (2017) 'Mänskliga rättigheter och andra konstitutionella kärnvärden när krisen slår till' in Lind, A. S., Namli, E. (szerk.) Mänskliga rättigheter i det offentliga Sverige. 1. kiadás. Lund: Studentlitteratur

HIRSCHFELDT, J. (2020) 'Svensk krishantering i fredstid - de konstitutionella aspekterna och en framåtblick', Svensk Juristtidning, 2020/10, 1148-1171. o.

IsBERG, M. (szerk.) (2016) The Constitution of Sweden. The Fundamental Laws and the Riksdag Act. 1. kiadás. Stockholm: Sveriges Riksdag

JoNSSON CORNELL, A. (2020) 'Författningsberedskap i praktiken - en kommentar med anledning av lagen om ändring i smittskyddslagen', Svensk Juristtidning, 2020/5, 377-381. o.

Jonsson CoRnell, A., Salminen, J. (2018) 'Emergency Laws in Comparative Constitutional Law - The Case of Sweden and Finland', German Law Journal, 19(2), 219-250. o.

Jonung, L. (2020) Sweden's Constitution Decides Its Covid-19 Exceptionalism [Online]. Elérhetô: https://project.nek.lu.se/publications/workpap/papers/wp20_11.pdf (Letöltve: 2020. december 1.)

Kiss, B. (1991) 'A svéd alkotmányfejlődés fóbb elemei', Acta Universitatis Szegediensis: Acta Juridica et Politica, 1991/1, 167-179. o.

Ludvigsson, J. F. (2020) 'The First Eight Months of Sweden's COVID-19 Strategy and the Key Actions and Actors that Were Involved', Acta Paediatr, 109(12), 2459-2471. o.

Mikкo, M. (2020) 'COVID-19 Policy in Sweden: Disaster or Object of Admiration?', Diplomaatia, 2020/201, 7-8. o.

Nergelius, J. J. (2013) 'Constitutional Reform in Sweden: Some Important Remarks', Tijdschrift voor Constitutioneel Recht, 2013/4, 372-379. o.

NeRgELiUS, J. J. (2018) Svensk statsrätt. 1. kiadás. Lund: Studentlitteratur

Nergelius, J. J. (2019) 'The Constitution of Sweden and European Influences: The Changing Balance Between Democratic and Judicial Power' in Albi, A., Bardutzky, S. (szerk.) National Constitutions in European and Global Governance: Democracy, Rights, the Rule of Law. Hague: T. M. C. Asser Press

ORTWEIN, B. M. II. (2003) 'The Swedish Legal System: An Introduction', Indiana International \&Comparative Law Review, 13(2), 405-445. o.

TAMÁs, A. (2011) 'Svédország közigazgatása' in Szamel, K., Balázs, I., Gajduschek, Gy., Koi, Gy. (szerk.) Az Európai Unió tagállamainak közigazgatása. 1. kiadás. Budapest: CompLex

Venice Commission (2020) Interim Reporton the Measures Taken in the EU Member States as a Result of the Covid-19 Crisis and Their Impact on Democracy, the Rule of Law and Fundamental Rights (Opinion No. 995/2020) [Online]. Elérhető: www.venice.coe.int/webforms/documents/ default.aspx?pdffile=CDL-AD(2020)018-e (Letöltve: 2020. december 15.) 